\title{
Hubungan Sumber Informasi dan Pengalaman dengan Tingkat Pengetahuan tentang Penggunaan Monosodium Glutamate (MSG) pada Ibu Rumah Tangga
}

\section{Correlation between Information Sources and Experience with Knowledge Levels about the Use of Monosodium Glutamate (MSG) in Housewives}

\author{
Yasmin Muntaza , Annis Catur Adi
}

\begin{abstract}
ABSTRAK
Latar Belakang: Monosodium Glutamate (MSG) adalah bahan tambahan pangan yang sering dimanfaatkan ibu rumah tangga sebagai penyedap rasa. Namun, penggunaan MSG masih menjadi kontroversial terutama dalam hal kesehatan. Hal ini dapat menyebabkan beragam informasi yang diperoleh ibu rumah tangga sehingga mempengaruhi penggunaan MSG dalam kehidupan sehari-hari.

Tujuan: Penelitian ini bertujuan untuk mengetahui hubungan sumber informasi dan pengalaman dengan tingkat pengetahuan tentang penggunaan MSG pada ibu rumah tangga.

Metode: Penelitian ini menggunakan desain penelitian cross sectional. Besar sampel sebanyak 86 ibu rumah tangga diambil menggunakan simple random sampling. Pengumpulan data meliputi karakteristik responden (umur, tingkat pendidikan terakhir, pekerjaan), sumber informasi, pengalaman, dan tingkat pengetahuan penggunaan MSG. Penelitian ini dianalisis menggunakan Uji Rank Spearman.

Hasil: Korelasi antara sumber informasi dengan tingkat pengetahuan tentang penggunaan MSG pada ibu rumah tangga memiliki hubungan yang signifikan ( $p$-value $<0,05)$, sedangkan pengalaman tidak memiliki hubungan yang signifikan dengan tingkat pengetahuan tentang penggunaan MSG pada ibu rumah tangga ( $p$-value $>0,05)$.

Kesimpulan: Ibu rumah tangga memiliki sumber informasi dan tingkat pengetahuan yang kurang terkait penggunaan MSG. Berdasarkan pengalamannya, MSG digunakan oleh ibu rumah tangga setiap hari dan masih dalam jumlah yang aman. Selain itu, ada hubungan yang signifikan antara sumber informasi dengan tingkat pengetahuan tentang penggunaan MSG pada ibu rumah tangga, sehingga peningkatan pengetahuan dapat melalui informan yang berpengaruh terhadap ibu rumah tangga seperti keluarga atau teman.
\end{abstract}

Kata kunci: Sumber informasi, pengalaman, pengetahuan, penggunaan MSG, ibu rumah tangga

\section{ABSTRACT}

Background: Monosodium Glutamate (MSG) is a food additive that is often used by housewives as flavoring. However, the use of MSG is still controversial, especially in terms of health. This can cause a variety of information obtained by housewives so that it affects the use of MSG in daily life.

Objectives: This study aimed to find out the relationship among information sources and experience with knowledge levels about the use of MSG in housewives.

Methods: This study used cross sectional design. The sample sizes were 86 housewives who were recruited through simple random sampling. The data collected including characteristics of respondents (age, level of education, occupation), information sources, experiences, and knowledge levels about the use of MSG. The result was analyzed using Rank Spearman Test.

Results: The correlation between information sources with knowledge levels about the use of MSG in housewives had a significant correlation ( $p$-value<0.05), mean while the correlation between experiences and knowledge levels about the use of MSG in housewives was not statistically significant ( $p$-value $>0.05$ ).

Conclusions: Housewives had less information sources and knowledge levels that related to the use of MSG. Based on experiences, housewives used MSG in every day and it was still in safe amounts. Furthermore, there were significant 
correlations between information sources with knowledge levels about the use of MSG, so the increase in knowledge can be through informants that affect housewives like a family or friends.

Keywords: Information sources, experiences, knowledge, use of MSG, housewives

\author{
*Koresponden: \\ Yasmin Muntaza \\ yasmin.muntaza@gmail.com \\ Departemen Gizi Kesehatan, Fakultas Kesehatan Masyarakat, Universitas Airlangga
}

\section{PENDAHULUAN}

Monosodium Glutamate (MSG) adalah bentuk garam dari asam glutamate, yaitu salah satu asam amino alami yang terkandung hampir pada semua makanan. Komposisinya terdiri dari $78 \%$ glutamate, $12 \%$ natrium, dan $10 \%$ air $^{1}$. MSG juga termasuk bahan tambahan pangan yang sering dimanfaatkan masyarakat Indonesia sebagai penyedap rasa. Hal ini disebabkan MSG memiliki ciri khas rasa gurih atau umami. Berdasarkan rujukan dari Joint Expert Committee on Food Additives (JECFA), Badan Pengawas Obat dan Makanan (BPOM) menyatakan bahwa MSG boleh digunakan dalam pangan dengan asupan harian yang dapat diterima tidak dinyatakan (Acceptable Daily Intake not specified/ADI not specified), yang berarti jumlah asupan bahan tambahan pangan tersebut dapat digunakan dalam takaran yang diperlukan untuk mencapai efek yang diinginkan ${ }^{2}$.

Di Indonesia, masalah penggunaan MSG masih menjadi kontroversial. Berawal dari isu Chinese Restaurant Syndrome (CRS) yang dinyatakan oleh Dr. Robert Ho Man Kwok (1969) sebagai pengalaman pribadi setelah mengkonsumsi makanan di rumah makan Cina. John Olney (1969) juga mengungkap MSG dapat merusak sel saraf jika dikonsumsi dengan dosis tinggi $(0,5-4,0 \mathrm{~g} / \mathrm{kg} \mathrm{BB})^{3}$. Ada pula yang menyatakan bahwa penggunaan garam dapur dan MSG lebih dari enam gram sehari dalam kurun waktu yang lama dapat mengakibatkan tekanan darah tinggi ${ }^{4}$. Berbagai penelitian juga telah dilakukan untuk menelusuri kebenaran dampak dari MSG. Namun, hasilnya ada yang pro dan kontra sehingga masih belum terungkap secara jelas.

Ibu rumah tangga merupakan seseorang yang biasa mengatur berbagai macam pekerjaan rumah tangga. Sebagian besar waktunya biasa digunakan untuk memelihara dan mengasuh anaknya, termasuk dalam hal mengatur makanan keluarganya ${ }^{5}$. Tidak menutup kemungkinan jika ibu rumah tangga akan menggunakan MSG dalam masakannya. Selain dituntut untuk mampu meningkatkan selera makan pada keluarganya, ibu rumah tangga juga perlu memiliki pengetahuan gizi yang baik. tentang golongan dan jenis bahan yang harus disajikan setiap kali makan, serta cara dalam memperlakukan bahan pangan agar tidak merusak kandungan zat gizinya ${ }^{6}$. Sama halnya dengan penggunaan bahan tambahan pangan seperti MSG, ibu rumah tangga harus tahu cara penggunaannya yang tepat, baik tentang dosis penggunaannya, cara menggunakannya saat memasak, hingga dampaknya bagi kesehatan.
Pengetahuan seseorang dapat ditingkatkan melalui faktor-faktor yang mempengaruhinya. Menurut Soekidjo, pengalaman dan sumber informasi memiliki pengaruh terhadap pengetahuan ${ }^{7}$. Sumber informasi dibagi menjadi empat kelompok yaitu sumber pribadi atau informasi yang berasal dari orang terdekat (keluarga, teman), sumber komersial (iklan, distributor, kemasan produk), sumber publik (media massa), dan sumber pengalaman yang merupakan evaluasi dari pemakaian produk $^{8}$. Sehingga dapat dikatakan bahwa pengalaman merupakan sumber informasi untuk memperoleh pengetahuan.

Berdasarkan latar belakang di atas, menunjukkan bahwa pengalaman dan sumber informasi memiliki keterkaitan dalam membentuk pengetahuan seseorang. Apabila dikaitkan dengan penggunaan MSG pada ibu rumah tangga, maka sumber informasi dan pengalaman penggunaan MSG ibu rumah tangga kemungkinan memiliki pengaruh terhadap pengetahuan tentang penggunaan MSG pada ibu rumah tangga. Oleh sebab itu, penelitian ini dilakukan untuk menganalisis gambaran sumber informasi, pengalaman, dan tingkat pengetahuan penggunaan MSG pada ibu rumah tangga di Desa Tebaloan, Kecamatan Duduksampeyan, Kabupaten Gresik. Hasil penelitian ini diharapkan dapat bermanfaat sebagai informasi, wawasan, dan bahan evaluasi untuk meningkatkan pengetahuan terkait penggunaan MSG.

\section{METODE}

Penelitian ini bersifat observasional dengan pendekatan cross sectional. Populasi sebanyak 581 ibu rumah tangga disesuaikan berdasarkan jumlah kartu keluarga yang tercatat di Desa Tebaloan, Kecamatan Duduksampeyan, Kabupaten Gresik. Pengambilan sampel menggunakan rumus Slovin dengan taraf signifikansi toleransi kesalahan sebesar $10 \%$ dan diperoleh 86 ibu rumah tangga. Sampel diambil secara acak menggunakan teknik simple random sampling pada aplikasi Microsoft Office Excel tahun 2010 dengan kriteria inklusi diantaranya bersedia menjadi responden, mampu berkomunikasi dengan baik, dan menggunakan MSG. Variabel dalam penelitian ini terbagi menjadi dua yaitu variabel bebas dan variabel terikat. Variabel bebasnya terdiri dari sumber informasi dan pengalaman dalam menggunakan MSG, sedangkan variabel terikatnya yaitu tingkat pengetahuan tentang penggunaan MSG.

Karakteristik ibu rumah tangga pada penelitian ini diantaranya usia dan tingkat pendidikan terakhir. Pengambilan data-data tersebut melalui wawancara 
menggunakan kuesioner. Sumber informasi dan pengalaman diukur dengan kuesioner yang masingmasing berisi tiga pertanyaan tanpa melalui uji validitas. Pengetahuan diukur dengan kuesioner berskala Gutman yang berisi empat pernyataan positif dan tiga pernyataan negatif. Kemudian total skor dikategorikan yang pilihannya terdiri dari baik jika skor $>80 \%$, cukup jika skor $60-80 \%$, dan kurang jika skor $<60 \%{ }^{9}$. Kuesioner pengetahuan telah melalui uji validitas item soal menggunakan Uji Pearson Product Moment dan hasil $r$ hitung $>r$ tabel.

Hasil penelitian dianalisis secara deskriptif dan analitik. Data yang dianalisis secara deskriptif meliputi semua variabel yang diteliti dalam penelitian ini, sedangkan analisis analitik dilakukan untuk mencari hubungan antara variabel bebas dengan variabel terikat menggunakan Uji Korelasi Rank Spearman pada software SPSS versi 20. Penelitian ini juga telah lulus etik oleh Komisi Etik Fakultas Ked okteran Gigi Universitas Airlangga Surabaya dengan sertifikat etik nomor 246/HRRECC.FODM/V/2019.

\section{HASIL DAN PEMBAHASAN}

Dalam penelitian ini, karakteristik ibu rumah tangga terdiri dari usia, tingkat pendidikan terakhir, dan pekerjaan yang disajikan pada tabel 1. Hasil menunjukkan bahwa sebagian besar ibu rumah tangga diketahui berusia 46 - 55 tahun sebanyak 30,0\%. Pengkategorian umur menurut Depkes tahun 2009, rentan umur tersebut termasuk masa lansia. Bertambahnya umur seseorang memiliki kaitan dengan pengalaman dan kematangan jiwa seseorang. Hal ini menyebabkan seseorang yang lebih dewasa akan lebih dipercaya $^{10}$.

Tabel 1 Distribusi Karakteristik Ibu Rumah Tangga di Desa Tebaloan

\begin{tabular}{lcc}
\multicolumn{1}{c}{ Karakteristik } & $\mathbf{n}$ & $\mathbf{\%}$ \\
\hline Usia & & \\
$17-25$ tahun & 3 & 3,0 \\
$26-35$ tahun & 15 & 17,0 \\
$36-45$ tahun & 17 & 20,0 \\
$46-55$ tahun & 26 & 30,0 \\
$56-65$ tahun & 20 & 23,0 \\
$>65$ tahun & 5 & 6,0 \\
\hline Total & 86 & 100,0 \\
\hline Tingkat Pendidikan Terakhir & & \\
SD/sederajat & 23 & 26,7 \\
SMP/sederajat & 22 & 25,6 \\
SMA/sederajat & 30 & 34,9 \\
Diploma I/II/III & 0 & 0,0 \\
Diploma IV/Strata I & 11 & 12,8 \\
\hline Total & 86 & 100,0 \\
\hline
\end{tabular}

Berdasarkan tingkat pendidikan terakhirnya, sebagian besar ibu rumah tangga diketahui lulusan SMA/sederajat sebanyak $34,9 \%$. Secara teori, pendidikan dapat mempengaruhi seseorang dalam menyerap informasi dan memahami pengetahuan. Semakin tinggi pendidikan maka semakin banyak informasi yang masuk dan pengetahuan yang diperoleh, termasuk pengetahuan tentang kesehatan. Namun, dalam penelitian Zaenurrohmah \& Rachmayanti menunjukkan bahwa orang yang memiliki pendidikan tinggi cenderung lebih tinggi mengalami hipertensi karena berkaitan dengan pekerjaan dan penghasilan yang diterimanya. Apabila ruang lingkup pekerjaan seseorang dikelilingi dengan orang-orang yang memiliki kebiasaan mengkonsumsi makanan berisiko dan ditambah penghasilan yang memadai, maka kondisi tersebut berpotensi untuk mempengaruhi preferensi makannya dalam mengkonsumsi makanan yang berisiko pula. Sehingga hal tersebutmenunjukkan bahwa seseorang yang berpendidikan tinggi tidak menjamin kesehatannya dapat terjaga dengan baik ${ }^{11}$.

Berdasarkan tingkat pekerjaan diketahui bahwa sebagian besar ibu rumah tangga/tidak bekerja sebanyak $61,6 \%$. Pekerjaan merupakan salah satu sarana menambah pengetahuan dan pengalaman ${ }^{7}$. Seseorang yang bekerja biasanya selalu dituntut untuk melakukan perubahan sesuai kebutuhan pekerjaannya. Agar dapat memenuhi kebutuhan tersebut dibutuhkan pula informasi yang lengkap dan cepat. Sehingga seseorang yang bekerja cenderung memiliki akses yang lebih baik tentang berbagai informasi ${ }^{12}$.

Tabel 2 menunjukkan bahwa distribusi berdasarkan jenis informasi pertama diketahui sebagian besar ibu rumah tangga pertama kali mengenal MSG dari ibu/keluarga sebanyak 66,3\%. Ada pula sumber informasi lainnya yaitu teman/tetangga/orang lain sebesar $20,9 \%$. Serta ibu rumah tangga yang mengenal MSG dari iklan sebesar $12,8 \%$.

Tabel 2. Distribusi Jenis dan Sumber Informasi Terkait Penggunaan MSG Ibu Rumah Tangga di Desa Tebaloan

\begin{tabular}{lcc}
\hline $\begin{array}{c}\text { Jenis dan Sumber Informasi Terkait } \\
\text { Penggunaan MSG }\end{array}$ & $\mathbf{n}$ & $\%$ \\
\hline $\begin{array}{l}\text { Pengenalan MSG Pertama Kali } \\
\text { lbu/keluarga }\end{array}$ & 57 & 66,3 \\
Teman/tetangga/orang lain & 18 & 20,9 \\
Petugas kesehatan & 0 & 0,0 \\
Iklan & 11 & 12,8 \\
\hline Total & 86 & 100,0 \\
\hline Dosis Aman Mengkonsumsi MSG & & \\
Tidak tahu & 85 & 98,8 \\
Ibu/keluarga & 0 & 0,0 \\
Teman/tetangga/orang lain & 0 & 0,0 \\
Petugas kesehatan & 0 & 0,0 \\
Iklan & 1 & 1,2 \\
\hline Total & 86 & 100,0 \\
\hline Cara Menggunakan MSG yang Tepat & & \\
Saat Memasak & 77 & 89,5 \\
Tidak tahu & 3 & 3,5 \\
Ibu/keluarga & 0 & 0,0 \\
Teman/tetangga/orang lain & 3 & 3,5 \\
Petugas kesehatan & 3 & 3,5 \\
Iklan & & \\
\hline Total & 86 & 100,0 \\
\hline
\end{tabular}

Berdasarkan jenis informasi kedua, sebagian besar ibu rumah tangga tidak mengetahui informasi tentang dosis aman mengkonsumsi MSG sebanyak 
$98,8 \%$. Tetapi ada beberapa ibu rumah tangga yang pernah mendapatkan informasi perihal tersebut dari iklan atau acara televisi sebanyak 1,2\%. Hasil wawancara menunjukkan bahwa informasi tentang dosis aman mengkonsumsi MSG sesuai dengan batas aman yang ditetapkan oleh Federation of American Societies for Experimental Biology (FASEB) yaitu tidak lebih dari 3,0 gram per hari atau hampir setara dengan $1 / 4$ sendok teh $^{13}$. Namun menurut FAO/WHO, konsumsi MSG diperbolehkan sebanyak $120 \mathrm{mg} / \mathrm{kg} \mathrm{BB} /$ hari $^{14}$.

Berdasarkan jenis informasi ketiga, sebagian besar ibu rumah tangga tidak mengetahui informasi tentang cara menggunakan MSG yang tepat saat memasak sebanyak $89,5 \%$. Hasil wawancara pada ibu rumah tangga yang mengaku pernah mendapatkan informasi perihal tersebut, cara menggunakan MSG yang tepat saat memasak yaitu di akhir proses memasak. Informasi tersebut sesuai karena MSG sebaiknya tidak diberikan ke makanan ketika berada dalam suhu tinggi untuk mencegah terbentuknya zat yang bersifat mutagenik dan karsinogenik $^{15}$.

Dari ketiga jenis informasi tersebut, dapat diketahui bahwa sumber informasi penggunaan MSG pada ibu rumah tangga sebagian besar dari ibu/keluarga. Umumnya ibu/keluarga dijadikan sebagai sumber informasi utama. Hal ini disebabkan ibu/keluarga dianggap sebagai orang terdekat sehingga lebih terbuka dalam mengungkapkan suatu hal atau bertukar informasi ${ }^{16}$.

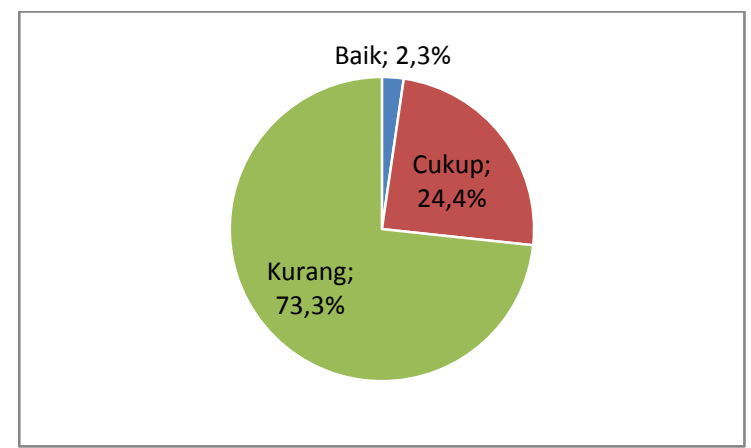

Gambar 1. Distribusi Tingkat Pengetahuan Penggunaan MSG Ibu Rumah Tangga di Desa Tebaloan Tahun 2019

Petugas kesehatan juga bisa sebagai sumber tambahan informasi. Petugas kesehatan dapat menambah informasi tentang kesehatan melalui kegiatan promosi kesehatan atau penyuluhan, baik secara langsung maupun menggunakan media tertentu. Dalam penelitian Cahyani penyuluhan melalui leaflet dan SMS dapat membuat pengetahuan ibu rumah tangga meningkat terkait penggunaan MSG, khususnya tentang takaran penggunaan MSG yang aman dan dampak penggunaan MSG yang berlebihan pada kesehatan ${ }^{17}$.

Selain itu, iklan juga bisa menjadi sumber informasi. Iklan adalah bentuk komunikasi personal yang terstruktur dan tersusun pada suatu informasi. Biasanya iklan memberikan informasi persuasif melalui suatu produk $^{18}$. Hasil penelitian Rangkuti juga menunjukkan bahwa iklan merupakan sumber informasi utama ibu rumah tangga dalam mengenal bumbu masak instan, terutama iklan di televisi. Perkembangan teknologi informatika dianggap mampu menarik perhatian ibu rumah tangga yang melihatnya karena dikemas dengan kreatif $^{19}$.

Tabel 3 menunjukkan bahwa berdasarkan frekuensi penggunaan MSG diketahui sebagian besar ibu rumah tangga menggunakan MSG setiap hari sebanyak $66,0 \%$ dan yang tidak menggunakan MSG setiap hari sebanyak $34,0 \%$. Ibu rumah tangga yang menggunakan MSG setiap hari mengaku bahwa jenis pengalaman tersebut sudah menjadi kebiasaan dan makanan terasa hambar jika tidak menggunakannya. Hasil penelitian ini sejalan dengan penelitian Prabekti yang menyatakan bahwa pemakaian MSG juga sudah menjadi kebiasaan pada wanita menikah ${ }^{20}$.

Berdasarkan jumlah MSG yang digunakan dalam sehari, diketahui bahwa sebagian besar ibu rumah tangga menggunakan MSG kurang dari satu sachet MSG terkecil atau kurang dari 0,5 gram/orang/hari. Apabila dibandingkan dengan anjuran dariFASEB, jumlah MSG yang digunakan oleh ibu rumah tangga di Desa Tebaloan juga masih dalam batas aman. FASEB menyebutkan bahwa batas aman konsumsi MSG yaitu sebesar 0,5 2,5 gram per hari atau tidak lebih dari 3,0 gram per hari bagi orang yang sensitif terhadap $\mathrm{MSG}^{14}$. Hasil penelitian ini tidak sama dengan hasil penelitian Murdiana yang menyatakan bahwa sebagian besar ibu rumah tangga di Pedesaan Bogor menggunakan MSG $1 / 2$ sendok teh setiap kali memasak ${ }^{21}$.

Tabel 3. Distribusi Jenis Pengalaman dalam Menggunakan MSG pada Ibu Rumah Tangga di Desa Tebaloan

\begin{tabular}{lcc}
\hline $\begin{array}{l}\text { Jenis Pengalaman dalam } \\
\text { Menggunakan MSG }\end{array}$ & $\mathbf{n}$ & $\mathbf{\%}$ \\
\hline $\begin{array}{l}\text { Frekuensi Penggunaan } \\
\text { MSG }\end{array}$ & 57 & 66,0 \\
$\begin{array}{l}\text { Setiap hari } \\
\text { Tidak setiap hari }\end{array}$ & 29 & 34,0 \\
\hline Total & 86 & 100,0 \\
\hline $\begin{array}{l}\text { Jumlah MSG yang } \\
\text { Digunakan per Orang } \\
\text { dalam Sehari } \\
<0,5 \text { gram }\end{array}$ & 82 & 95,3 \\
$\begin{array}{l}\geq 0,5 \text { gram } \\
\text { Total }\end{array}$ & 4 & 4,7 \\
\hline Reaksi Pertama Kali & & \\
$\begin{array}{l}\text { Menggunakan MSG } \\
\begin{array}{l}\text { Ada } \\
\text { Tidak ada }\end{array}\end{array}$ & 36 & 100,0 \\
\hline Total & 83 & 96,5 \\
\hline & 86 & 100,0 \\
\hline
\end{tabular}

Berdasarkan reaksi pertama kali menggunakan MSG, diketahui bahwa sebagian besar ibu rumah tangga mengaku tidak ada reaksi atau baik-baik saja saat pertama kali mengkonsumsi MSG. Hasil ini tidak sejalan dengan hasil beberapa penelitian yang menyatakan bahwa MSG pemicu timbulnya gejala Chinese Restaurant Syndrome (CRS) seperti leher dan dada panas, sesak nafas, dan kepala pusing, serta gangguan kesehatan lainnya seperti kerusakan sel jaringan otak dan kanker ${ }^{22}$. 
Tabel 4 menunjukkan sebagian besar ibu rumah tangga memiliki tingkat pengetahuan yang kurang terkait penggunaan MSG sebanyak 73,3\%. Sama halnya pada penelitian yang dilakukan Adiyasa dkk dimana sebagian besar tingkat pengetahuan ibu rumah tangga tentang penggunaan penyedap rasa juga masih kurang ${ }^{16}$. Salah satu faktor yang mempengaruhinya yaitu kurangnya informasi yang diperoleh ibu rumah tangga. $\mathrm{Hal}$ ini didukung dengan hasil penilaian kuesioner dimana ibu rumah tangga terbatas dalam menyebutkan sumber informasi tentang penggunaan MSG, serta hasil wawancara dengan ibu rumah tangga yang mengaku tidak pernah mendapatkan penyuluhan dari petugas

Tabel 5 menunjukkan bahwa ada empat pernyataan yang memiliki jumlah terkecil untuk dijawab secara benar oleh ibu rumah tangga. Pernyataan pertama tentang rasa terhadap MSG,ebagian besar ibu rumah tangga yang menganggap makanan asin selalu mengandung garam dan MSG. Pada dasarnya rasa asin berasal dari garam, mentega, dan margarin ${ }^{23}$. Sedangkan MSG tidak menciptakan rasa asin, melainkan gurih ${ }^{1}$. Pernyataan kedua tentang kandungan natrium pada MSG, sebagian kecil ibu rumah tangga yang mengetahui bahwa MSG mengandung natrium. Berdasarkan hasil wawancara, banyak ibu rumah tangga yang lebih mengenal garam sebagai sumber natrium dibandingkan kesehatan dan kurang menyempatkan diri untuk mencari informasi terkait MSG, baik melalui media elektronik, media cetak, maupun internet.

Tabel 4. Distribusi Tingkat Pengetahuan Penggunaan MSG Ibu Rumah Tangga di Desa Tebaloan

\begin{tabular}{lcc}
\hline $\begin{array}{c}\text { Jenis Pengalaman dalam } \\
\text { Menggunakan MSG }\end{array}$ & n & \% \\
\hline Baik & 2 & 2,3 \\
Cukup & 21 & 24,4 \\
Kurang & 63 & 73,3 \\
\hline Total & 86 & 100,0 \\
\hline
\end{tabular}

MSG. Pernyataan ketiga tentang jumlah kandungan narium pada MSG, sebagian kecil ibu rumah tangga yang mengetahui bahwa kandungan natrium pada MSG lebih kecil dari garam. Pernyataan keempat tentang cara pemberian MSG yang tepat saat memasak, sebagian kecil ibu rumah tangga yang mengetahui bahwa pemberian MSG yang tepat saat memasak adalah di akhir proses memasak. Sehingga dari hasil tersebut dapat diketahui bahwa ibu rumah tangga banyak yang belum mengetahui sifat atau ciri khas rasa dari MSG, kandungan natrium pada MSG, dan cara penggunaan MSG yang tepat saat memasak.

Tabel 5. Distribusi Ibu Rumah Tangga Berdasarkan Jawaban yang Benar pada Pernyataan Kuesioner Pengetahuan di Desa Tebaloan

\begin{tabular}{llcc}
\hline No. & \multicolumn{1}{c}{ Pernyataan } & $\mathbf{n}$ & $\%$ \\
1 & Membatasi konsumsi garam dan makanan asin termasuk upaya untuk menuju gizi & 65 & 75,6 \\
& seimbang. & 6 & 7,0 \\
2 & Makanan asin tidak selalu mengandung garam dan MSG/vitsin/micin. & 42 & 48,8 \\
3 & MSG/vitsin/micin berasal dari tetesan atau sari tebu. & 43 & 50,0 \\
4 & Harga MSG/vitsin/micin lebih mahal daripada garam. & 25 & 29,1 \\
5 & MSG/vitsin/micin mengandung natrium. & 9 & 10,5 \\
6 & MSG/vitsin/micin mengandung natrium yang lebih kecil daripada garam. & 33 & 38,4 \\
7 & Pemberian MSG/vitsin/micin ke masakan yang tepat adalah setelah masakan matang. & & \\
\hline
\end{tabular}

Pada variabel sumber informasi dilakukan penggabungan kategori dengan menetapkan mean pilihan jawaban dari setiap jenis sumber informasi yang selanjutnya dikategorikan ke kategori "Ada" dan "Tidak Ada". Berdasarkan hasil uji statistik menunjukkan bahwa ada hubungan yang signifikan antara sumber informasi dengan tingkat pengetahuan tentang penggunan MSG ibu rumah tangga ( $p$-value $=0,001)$. Tidak adanya sumber informasi pada ibu rumah tangga diketahui dapat menyebabkan pengetahuan berkurang. Hal ini ditunjukkan dari hasil distribusi ibu rumah tangga yang memiliki tingkat pengetahuan kurang terbanyak pada kategori tidak adanya sumber informasi.

Hasil penelitian ini tidak sejalan dengan penelitian yang dilakukan Istiqomah dkk yang diketahui tidak ada hubungan signifikan antara akses informasi dengan pengetahuan pada pedagang bakso yang menambahkan bahan tambahan pangan berupa boraks di Kota Bengkulu. Namun dari gambaran distribusi sumber atau akses informasi dengan pengetahuan menunjukkan hasil yang sama dengan penelitian ini, dimana responden yang memiliki tingkat pengetahuan baik disebabkan memiliki akses informasi yang jelas, sedangkan responden yang memiliki tingkat pengetahuan kurang disebabkan kurangnya akses informasi ${ }^{24}$.

Secara teori sumber informasi dapat memberikan pengaruh terhadap pengetahuan dimana seseorang akan menerima landasan kognitif untuk membentuk pengetahuan. Menurut Carolina dkk, semakin banyak sumber informasi, maka semakin banyak pula pengetahuan yang diperoleh. Keleher et al juga menambahkan bahwa sumber informasi terkait kesehatan diakui sebagai determinan kunci dari kesehatan. Informasi kesehatan dapat diperoleh melalui berbagai cara seperti penyuluhan, pendidikan dan pelatihan kesehatan, media massa, media elektronik, dan lainnya ${ }^{25}$.

Hasil uji statistik juga menunjukkan bahwa tidak ada hubungan yang signifikan antara pengalaman dengan tingkat pengetahuan tentang penggunan MSG ibu rumah tangga. Hal ini dapat dilihat pada Tabel 6 dimana hasil tabulasi silang antara setiap jenis pengalaman diantaranya frekuensi penggunaan MSG, jumlah MSG yang digunakan dalam sehari, dan reaksi pertama kali menggunakan MSG dengan tingkat pengetahuan tentang penggunan MSG ibu rumah tangga 
diperoleh $p$-value $>0,05$. Pada jenis pengalaman pertama diketahui distribusi ibu rumah tangga yang memiliki tingkat pengetahuan kurang cenderung menggunakan MSG setiap hari. Pada jenis pengalaman kedua diketahui distribusi ibu rumah tangga yang memiliki tingkat pengetahuan kurang cenderung menggunakan MSG kurang dari 0,5 gram/orang/hari. Diketahui pula bahwa tidak ada ibu rumah tangga dengan tingkat pengetahuan baik yang menggunakan MSG lebih dari 0,5 gram/orang/hari. Hal ini menunjukkan ibu rumah tangga dengan tingkat pengetahuan yang baik cenderung memiliki pengalaman yang baik pula, khususnya dalam menentukan jumlah penggunaan MSG. Penggunaan MSG ibu rumah tangga dalam penelitian ini masih termasuk aman menurut FASEB sehingga dapat dikatakan bahwa sebagian besar ibu rumah tangga memiliki pengalaman yang baik terkait jumlah penggunaan MSG per hari. Pada jenis pengalaman ketiga diketahui distribusi ibu rumah tangga yang memiliki tingkat pengetahuan kurang cenderung tidak ada reaksi saat pertama kali menggunakan MSG.

Tabel 6. Hubungan Sumber Informasi dan Pengalaman dengan Tingkat Pengetahuan tentang Penggunaan MSG di Desa Tebaloan, Kecamatan Duduksampeyan, Kabupaten Gresik

\begin{tabular}{|c|c|c|c|c|c|c|c|}
\hline \multirow{3}{*}{ Variabel yang Diteliti } & \multicolumn{6}{|c|}{ Tingkat Pengetahuan } & \multirow{3}{*}{$p$-value } \\
\hline & \multicolumn{2}{|c|}{ Baik } & \multicolumn{2}{|c|}{ Cukup } & \multicolumn{2}{|c|}{ Kurang } & \\
\hline & $\mathbf{n}$ & $\%$ & $\mathbf{n}$ & $\%$ & $\mathbf{n}$ & $\%$ & \\
\hline \multicolumn{8}{|l|}{ Sumber Informasi } \\
\hline Ada & 1 & 50,0 & 6 & 28,6 & 3 & 4,8 & 0,001 \\
\hline Tidak ada & 1 & 50,0 & 15 & 71,4 & 60 & 95,2 & \\
\hline Total & 2 & 100,0 & 21 & 100,0 & 63 & 100,0 & \\
\hline \multicolumn{8}{|l|}{ Frekuensi Penggunaan MSG } \\
\hline Setiap hari & 1 & 50,0 & 12 & 57,1 & 44 & 69,8 & 0,247 \\
\hline Tidak setiap hari & 1 & 50,0 & 9 & 42,9 & 19 & 30,2 & \\
\hline Total & 2 & 100,0 & 21 & 100,0 & 63 & 100,0 & \\
\hline \multicolumn{8}{|l|}{$\begin{array}{l}\text { Jumlah MSG yang Digunakan } \\
\text { per Orang dalam Sehari }\end{array}$} \\
\hline$<0,5$ gram & 2 & 100,0 & 20 & 95,2 & 60 & 95,2 & 0,916 \\
\hline$\geq 0,5$ gram & 0 & 0,0 & 1 & 4,8 & 3 & 4,8 & \\
\hline Total & 2 & 100,0 & 21 & 100,0 & 63 & 100,0 & \\
\hline \multicolumn{8}{|l|}{ Reaksi Pertama Kali } \\
\hline Ada & 0 & 0,0 & 0 & 0,0 & 3 & 95,2 & 0,294 \\
\hline Tidak ada & 2 & 100,0 & 21 & 100,0 & 60 & 4,8 & \\
\hline Total & 2 & 100,0 & 21 & 100,0 & 63 & 100,0 & \\
\hline
\end{tabular}

Tidak adanya hubungan antara pengalaman dengan tingkat pengetahuan ibu rumah tangga disebabkan pernyataan untuk menilai pengetahuan tidak mencakup semua jenis pengalaman dalam menggunakan MSG. Penilaian pengetahuan juga membahas tentang rasa MSG, kandungan MSG, bahan dasar MSG, perbandingan harga MSG dengan garam, serta cara menggunakan MSG yang tepat saat memasak. Selain itu pengetahuan juga dapat disebabkan adanya faktor lain yang mempengaruhi pengetahuan seperti pendidikan, umur, dan sumber informasi ${ }^{26}$.

\section{KESIMPULAN}

MSG digunakan oleh ibu rumah tangga setiap hari dan masih dalam jumlah yang aman karena kurang dari 3,0 gram/orang/hari saat memasak. Ada hubungan yang signifikan antara sumber informasi dengan tingkat pengetahuan tentang penggunaan MSG. Ibu rumah tangga yang memiliki tingkat pengetahuan kurang karena kurangnya sumber infomasi, sehingga perlu ditingkatkan pengetahuan ibu rumah tangga tentang penggunaan MSG, terutama informasi tentang sifat atau ciri khas rasa dari MSG, kandungan natrium pada MSG, dan cara penggunaan MSG yang tepat saat memasak.

\section{ACKNOWLEDGEMENT}

Peneliti mengucapkan terima kasih kepada ibu rumah tangga yang telah bersedia menjadi responden dan meluangkan waktu untuk berpartisipasi dalam penelitian ini. Penulis juga berterima kasih kepada pihakpihak yang terlibat dalam proses penelitian hingga penelitian ini dapat terlaksana.

\section{REFERENS}

1. Yonata, A. \& Iswara, I. Efek Toksik Konsumsi Monosodium Glutamate. Majority 5, 100-104 (2016).

2. Badan Pengawas Obat dan Makanan RI. Peraturan Kepala Badan Pengawas Obat dan Makanan RI Nomor 23 Tahun 2013 Tentang Batas Maksimum Penggunaan Bahan Tambahan Pangan Penguat Rasa. (2013).

3. Cahyadi, W. Analisis dan Aspek Kesehatan Bahan Tambahan Pangan. (Bumi Aksara, 2012).

4. Dendra, I. M. \& Oktavia, S. Hubungan Tingkat Konsumsi Energi dan Natrium dengan Penderita Hipertensi di Kelurahan Malalayang I Kota Manado. J. Gizido 9, 14-27 (2017).

5. Kartono, K. Psikologi Wanita Jilid II (Mengenal 
Wanita Sebagai Ibu dan Nenek). (Mandar Maju, 2011).

6. Adriani, M. \& Wirjatmadi, B. Pengantar Gizi Masyarakat. (Kencana, 2012).

7. Soekidjo, N. Promosi Kesehatan dan Perilaku Kesehatan. (Rineka Cipta, 2012).

8. Kotler, P. T. \& Keller, K. L. Marketing Management: Twelfth Edition. (Pearson, 2006).

9. Khomsan, A. Teknik Pengukuran Pengetahuan dan Gizi Cetakan I. (Swadaya, 2000).

10. Wawan, A. \& Dewi. Teori dan Pengukuran Pengetahuan, Sikap dan Perilaku Manusia. (Nuha Medika, 2011).

11. Zaenurrohmah, D. H. \& Rachmayanti, R. D. Hubungan Pengetahuan dan Riwayat Hipertensi dengan Tindakan Pengendalian Tekanan Darah pada Lansia. J. Berk. Epidemiol. 5, 174-184 (2013).

12. Soekidjo, N. Pendidikan dan Perilaku Kesehatan. (Rineka Cipta, 2003).

13. Elpiana. Pengaruh Monosodium Glutamat Terhadap Kadar Hormon Testosterone dan Berat Testis pada Tikus Putih Jantan (Rattus norvegicus). (Universitas Andalas, 2014).

14. Ratnani, R. D. Bahaya Bahan Tambahan Makanan Bagi Kesehatan. Momentum 5, 16-22 (2009).

15. Adiyasa, I. N., Abdi, L. K. \& Fujiawati, R. Tingkat Pengetahuan Ibu, Peran Petugas Kesehatan dan Perilaku Penggunaan Penyedap Rasa Monosodium Glutamat (MSG) pada Masakan. J. Kesehat. Prima 10, 1756-1766 (2016).

16. Kurniasih, N. \& Komariah, N. Peta Pencarian Informasi Kesehatan Reproduksi Remaja Kota Bandung Berdasarkan Jenis Kelamin, Latar Belakang Pendidikan, Status Sosial dan Ekonomi. in Prosiding Simposium Nasional Komunikasi Kesehatan 2015 251-265 (Lembaga Penelitian, Pengabdian kepada Masyarakat dan Penerbitan (LP3) Fikom UNPAD, 2016).

17. Cahyani, P. Pengaruh Penyuluhan dengan Media Leaflet dan SMS terhadap Perilaku Ibu
Rumah Tangga dalam Penggunaan Monosodium Glutamat di Kelurahan Rambung Timur Kecamatan Binjai Selatan Tahun 2016. (Universitas Sumatera Utara, 2016).

18. Arens, A. A., Elder, R. J. \& Beasley, M. S. Auditing \& Jasa Assurance. (Erlangga, 2011).

19. Rangkuti, R. P. W. Hubungan Pengetahuan dan Sikap dengan Tindakan Ibu Rumah Tangga dalam Penggunaan Bumbu Masak Instan di Kelurahan Tanjung Sari Kecamatan Medan Selayang Kota Medan. (Universitas Sumatera Utara, 2018).

20. Prabekti, R. A. A. Sikap Wanita Menikah dalam Pemakaian Penyedap Makanan (MSG).

(Universitas Muhammadiyah Malang, 2016).

21. Murdiana, E. Analisis Penggunaan Monosodium Glutamat (MSG) pada Ibu Rumah Tangga di Perkotaan dan Perdesaan Bogor. (Institut Pertanian Bogor, 2012).

22. Priyoto. Perubahan dalam Perilaku Kesehatan; Konsep dan Aplikasi. (Graha IImu, 2015).

23. Kementerian Kesehatan RI. Pedoman Gizi Seimbang. (2014).

24. Istiqomah, S., Sudarwanto, M. B. \& Sudarnika, E. Penambahan Boraks dalam Bakso dan Faktor Pendorong Penggunaannya Bagi Pedagang Bakso di Kota Bengkulu. J. Sain Vet. 34, 1-8 (2016).

25. Carolina, P., Carolina, M. \& Lestari, R. M. Hubungan Tingkat Pengetahuan dan Sumber informasi dengan Penerapan Perilaku Hidup Bersih dan Sehat (PHBS) pada Keluarga di Wilayah Kerja Pustu Pahandut Seberang Kota Palangka Raya Tahun 2016. Enviro Sci. 12, 330337 (2016).

26. Jamil, A., Sabilu, Y. \& Munandar, S. Gambaran Pengetahuan, Sikap, Tindakan dan Identifikasi Kandungan Pemanis Buatan Siklamat pada Pedagang Jajanan Es di Kecamatan Kadia Kota Kendari Tahun 2017. J. Ilm. Mhs. Kesehat. Masy. 2, 1-11 (2017) 